\title{
DECIR VERDAD, HACER FICCIÓN: PARA UNA REVISIÓN DEL AFORISMO
}

\author{
ERIKA MARTÍNEZ \\ Universidad de Granada
}

\begin{abstract}
RESUMEN: ¿Cómo afrontar la revisión del estatuto aleteico del aforismo? Para responder a la pregunta y con Nicolás Gómez Dávila como referente, analizaremos su relación con lo falso o lo probable, su tendencia a la refutación o la iconoclastia, así como la forma conflictiva en que sus proposiciones se relacionan con lo común o constituyen verdades de vida. El carácter complejo de su condición genérica exige asimismo un estudio de las implicaciones enunciativas de su estatuto de ficción y de la manera en que sus lectores actualizan cierta búsqueda figurada de la verdad mediante una revelación epifánica del sentido. Finalmente, una aproximación genealógica al aforismo, sus juegos de verdad y discursos de veridicción apunta a dos aportaciones del último Foucault, el decir verdad del parresiasta y los hypomnematas, así como a una consideración del aforismo como un ritual vivo de la verdad.
\end{abstract}

PALABRAS CLAVE: aforismo; verdad; ficción; lírica; Michel Foucault; Nicolás Gómez Dávila.

\section{Truth telling, making fiction: for a review of the aphorism}

ABSTRACT: A clarification of the aleteic status of the aphorism entails a revision of some major keys for its critical elucidation: its relation to the false or the probable, its tendency to refutation or iconoclasty, as well as the conflicting way in which its propositions are related to the common or constitute truths of life. The complex nature of its generic condition also requires a review of the enunciative implications of its fiction status and the way in which its readers actualize a certain figurative search for truth through an epiphanic revelation of meaning. Finally, a genealogical approach to the aphorism, its truth games and veridiction speeches points to some contributions of the last Foucault, the truth-telling of the parresiasta and the hypomnematas, as well as a consideration of the aphorism as a living ritual of the truth.

KEY WORDS: aphorism; true; fiction; lyrical poetry; Michel Foucault; Nicolás Gómez Dávila.

1. El estatuto aleteico del aForismo

La verdad no se cultiva de frente, sino de flanco.

Nicolás Gómez Dávila

¿Tiene un aforismo condición de verdad? ¿La cuestiona desde sus fundamentos? ¿De qué forma se relaciona con ella? ¿Aspira acaso a la veridicción? Toda aproximación teórica al género pasa de uno u otro modo por esta controversia, cuya complejidad no ha dejado de transformarse a lo largo de la historia.

Para Renzo Tosi, la Grecia arcaica heredó de la vecina koiné oriental el amor por estas formas breves que sintetizan una «norma de validez universal», recurriendo a una formulación lapidaria para su mnemotecnia ${ }^{1}$. Su carácter inicial

1 TosI, R., «I Greci: gnomai, paroimiai, apophthegmata», en: Eco et al., Teoria e storia dell'aforisma, Mondadori, Milán 2004, p. 15. 
de precepto se verá impregnado muy pronto de un fuerte componente gnómico, que añadió al elemento doctrinal y moral de la sentencia una voluntad de conocimiento y formulación de la verdad. Si la norma del aforismo grecolatino debía poseer validez universal, podríamos decir que su estatuto aleteico era de carácter general.

La máxima conservó aquella aspiración: trascender al individuo y a la historia a través de una afirmación veraz, verosímil o probable que - como ha escrito Roukhomovsky - comparte una comunidad ${ }^{2}$. Estos rasgos, propios de la máxima, siguen atribuyéndose a veces al aforismo, ignorando su desarrollo a lo largo de los siglos. Es el caso de algunas de las definiciones recogidas por Marco Ángel en un artículo publicado en la revista Quimera. En él repasa las entradas de varios diccionarios de estilística y términos literarios donde se atribuye al aforismo la expresión de una verdad gnómica (o al menos de una parte de la verdad), asociándolo a un conocimiento y sabiduría compartidos sin considerar su historicidad. Para Ángel, sin embargo, «la verdad que el aforismo expresa estará relacionada con la tradición a la que pertenece», lo cual explicaría algunas de las contradicciones que se generan entre aforismos ${ }^{3}$. A dicha afirmación podría añadirse que no solo se transforma lo que es o no verdad en cada tradición, sino la propia idea de verdad. En The Advancement of Learning (1605), Francis Bacon consideraba que el aforismo desbarata las ideas preconcebidas, provoca a la curiosidad en vez de satisfacerla y constituye un saber truncado. Frente al método magistral de conocimiento, caracterizado por la coherencia, la sistematicidad y el autoritarismo, los aforismos serían - según Bacon - una forma de conocimiento que no se presenta a sí misma como cerrada, sino a través de fragmentos en proceso, «in growth $»^{4}$. Su fuerte potencial cognitivo les permite dar cuenta de las observaciones y los conceptos sin someterlos a construcciones cerradas. Y su flexibilidad resulta adecuada para aquellos asuntos vinculados a lo particular o a la forma múltiple de la materia: «Aphorisms, representing a knowledge broken, do invite men to inquire further; whereas Methods, carrying the show of a total, do secure men, as if they were at furthest ${ }^{5}$.

Frente a la idea de la máxima como verdad compartida, Salvatore Veca entiende que es la teoría la que trata de reducir la incertidumbre de la vida en común, participando en la constitución de una comunidad estable. En sus variantes contemporáneas, el aforismo se distinguiría, sin embargo, del pensamiento teórico encarnando una «variedad no contradictoria de interpretaciones

2 Rouкномоvsкy, B., Lire les formes brèves, Nathan, París 2001, p. 63 (citado por José Ramón González, «Introducción», en: Pensar por lo breve. Aforística española de entresiglos. Antología (1980-2012), Trea, Gijón 2013, p. 25).

3 MARco, Á., «Aforismo: problemas de la definición», en: Quimera. Revista de Literatura, n. ${ }^{\circ} 442$, febrero de 2019, p. 13.

4 Bacon, F., The Advancement of Learning, en: The Major Works, Oxford University Press, Oxford 2008, II, p. 215.

5 Ibid., p. 235. 
de lo disponible», generando incertidumbre en vez de disolverla ${ }^{6}$. Diríamos, por tanto, que al contrario que el aforismo clásico, el aforismo contemporáneo ${ }^{7}$ tiene un estatuto aleteico de precariedad: su verdad es siempre parcial y provisoria, depende de las circunstancias de su formulación.

En su relación con la verdad, el aforismo contemporáneo podría definirse como una forma de transgresión de la máxima, pero lo cierto es que ambos poseen demasiado en común para ser considerados géneros independientes. Werner Helmich prefirió, por ello, distinguir tres tipologías: el aforismo conceptual (o máxima, cuya sorpresa sería intelectual), el metafórico (cuya sorpresa sería imaginativa) y el analógico (o greguería) ${ }^{8}$. Es sin duda el aforismo metafórico, poético o lírico una variante largamente practicada en los siglos XX y XXI. Sobre ella ha reflexionado en profundidad Carmen Camacho:

La relevancia de la condición poética de los aforismos se fundamenta en una visión que, más allá de los límites promovidos por la lógica y la razón especulativa, ensancha sus dominios mediante la intuición, la contemplación, los sueños, el sentimiento —entendido como algo no opuesto a la razón-, la imaginación y hasta la sinrazón. Imágenes, símbolos, metáforas: el lenguaje poético deviene lenguaje natural de una manera distinta, más abarcadora de palpar lo Real'.

Este aforismo poético seguiría nutriéndose hoy de algunos elementos de la literatura de vanguardia y del fragmento romántico, de su concepto iluminado de la verdad y de su apelación no racionalista a la intuición.

Escribió Nicolás Gómez Dávila que «acusar a un aforismo de no expresar sino parte de la verdad equivale suponer que el discurso prolijo puede expresarla toda ${ }^{10}$. Más allá de su parcialidad, la falsedad de un aforismo, su mentira o incluso su deshonestidad han sido cuestiones tan largamente discutidas como la de su verdad. «Cancerizable» es el adjetivo utilizado por Umberto Eco para referirse a los aforismos reversibles, cuyas dos versiones opuestas son mentira o arbitrarias, aunque pasen por verdades gracias al ingenio. Los «aforismos cancerizables» vendrían a sumarse, según Eco a las «falsas paradojas» (lugares

6 VeCA, S., "Aforisma e filosofia», en: Eco et al., Teoria e storia dell'aforisma, Mondadori, Milán 2004, pp.128 y 129.

7 Utilizamos este término aquí y en adelante para nombrar a las variantes del género desarrolladas en la Edad Contemporánea, o sea, desde mediados del siglo XVIII hasta la actualidad, tratando de evitar con ello la ambigüedad histórica del adjetivo «moderno» en castellano.

8 Helmich, W., «L'aforisma come genere letterario», en: Rigoni, Mario Andrea (ed.), La brevità felice. Contributi alla teoria e alla storia dell'aforisma, Marsilio Editori, Venecia 2006, p. 44.

9 Cамасно, C., "Las ínsulas extrañas» (prólogo), en: Fuegos de palabras. El aforismo poético español de los siglos XX y XXI (1900-2014), Vandalia, Sevilla 2018, p. 31.

10 Gómez Dávila, N., Escolios a un texto implícito,Villegas Editores, Bogotá 2001, p. 381. En adelante, ilustraremos algunas de las reflexiones de este artículo con los escolios del aforista colombiano Nicolás Gómez Dávila (1913-1994), por la tensión que introducen desde la crítica a la Modernidad. 
comunes formulados como si no lo fueran) y a los «aforismos deshonestos» (que pueden pasar por verdaderos a pesar contradecir a la opinión común) ${ }^{11}$. Todas estas variantes se opondrían a la paradoja, que sí es capaz de generar conocimiento a través de los contrarios. En su Diccionario de la sinceridad (1953), Pitigrilli otorga la misma dignidad que Eco a la paradoja, por su capacidad de contradecir las opiniones establecidas ${ }^{12}$.

En una caracterización no histórica del género, Umberto Eco concluye que tanto el aforismo como la sentencia y el proverbio son portadores de una opinión aceptada o aceptable. Y añade: «El aforismo nunca dice la verdad sino lo probable, en ciertas circunstancias y desde cierto punto de vista» ${ }^{13}$. O sea, sobreentiende una negociación para decidir la condición de su aceptabilidad. Eso que podría vincularse con el endoxon, lugar común o idea aceptada por la comunidad. Para Eco, en tanto entimema, el aforismo sería un silogismo basado en una premisa que se apoya en la experiencia aceptada. Al ser solo probable, el aforismo es contestable, por muy persuasivo que sea ${ }^{14}$. Un aforismo, podríamos añadir, exige su propia refutación. Y lo hace mediante una interpelación crítica, paradójica y latente que adopta una formulación taxativa mientras repudia las verdades absolutas. «Los libros serios no instruyen —anota Gómez Dávila- sino interpelan» ${ }^{15}$.

Partiendo de todo lo dicho hasta ahora, cabría preguntarse si una comunidad comparte o no comparte lo que propone un aforismo. Lejos de algunas de las caracterizaciones hechas por la crítica, se diría que el género tiene algo de verdad que puede no ser adherida por la comunidad donde se enuncia, al menos en sus variantes contemporáneas ${ }^{16}$. Dichas variantes pueden ser consideradas como un "pensamiento de lo impensable», o al menos así traté de analizarlas en otro lugar:

Su propósito furtivo parece ser a menudo la discusión de convenciones, lugares comunes, ideas que han perdido capacidad de litigio. De hecho, con diferentes grados de violencia, el aforismo acostumbra a profanar precisamente aquello que ha sido expulsado del juego polémico, aquello que no podía ser pensado ni discutido, que se sustrajo de la subjetivación política. (...) Su palabra viene ejerciendo cierta vocación de litigio en un espacio limítrofe a la poesía y la filosofía. Dicha vocación es, de hecho, la que lo contrapone

11 Eco, U., «Note sull'aforisma. Statuto aletico e poetico del detto breve», en: Eco et al., Teoria e storia dell'aforisma, Mondadori, Milán 2004, pp. 160-164.

12 Por el contrario, según Pitigrilli, el aforismo se correspondería con la formulación brillante del lugar común (Diccionario de la sinceridad, Barcelona, Planeta 1965. $1^{\text {a }}$ ed. 1953, Dizionario Antiballistico). Nosotros nos inclinamos por una definición del aforismo contemporáneo como refractario a los lugares comunes, siendo la paradoja un procedimiento propio del género y no en sí un género aparte.

13 Ibíd., p. 159.

14 Ibid., p. 155.

15 Ibid., p. 98.

16 Para Eco, esa sería una característica de la paradoja, aunque nosotros lo extrapolemos al aforismo contemporáneo (Ibid., p. 164). 
a otros géneros en teoría afines como los refranes, a los que sin embargo se presupone una entidad ecuménica ${ }^{17}$.

Para André Jolles, los dichos, refranes y su palabra gnómica son «formas simples de la poesía popular» ${ }^{18}$, que comparten con el aforismo su brevedad pero no el carácter literario. Yo diría, por el contrario, que refrán popular y aforismo contemporáneo comparten tanto la brevedad como el carácter literario, siendo antagonistas en su diferente vocación ecuménica y de litigio. Podría considerarse, con Helmich, que el aforismo tiene algo de deformación lúdica o crítica del proverbio, o incluso de imitación paródica ${ }^{19}$. Será precisamente el carácter de litigio que posee el aforismo lo que lo distinguirá también de otras formas breves, rotundas y con voluntad de impacto, que adoptan un tono pseudofilosófico, como son los eslóganes publicitarios. De hecho, a diferencia del aforismo contemporáneo, los eslóganes abogarían — según James Geary— «por la homogeneidad de patrones de compra o de voto, como mínimo, y no por la iconoclasia ${ }^{20}$.

El aforismo sometería el lenguaje y la lógica a este desvío paródico, haciendo un uso impropio o extraño de los principios de la ciencia y la gramática, según Adorno. La paradoja del género sería así su despliegue de un no-saber, algo que presupone la «reflexión extrema del saber» ${ }^{21}$.

Desde sus orígenes arcaicos, el aforismo ha tendido a un manejo de los contrarios capaz de movilizar los instrumentos de la razón dialógica:

Lo cierto, sin embargo, es que también se posiciona frente a la idea de que un conflicto entre opuestos deriva en la afirmación de algo. Quizás, en todo caso, resultaría más apropiado estudiar el género a la luz de la dialéctica negativa de Adorno y el carácter inconcluso de toda contradicción. Más que en la síntesis, su conocimiento descansa en la paradoja (...). Si, como hemos señalado, el aforismo tiene algo de discurso en desacuerdo, también podría decirse con Derrida que su asociación de ideas llega demasiado pronto o demasiado tarde, siempre en el momento equivocado. Sus referencias se cruzan en diferentes direcciones, quedando así desdibujado —igual que en la reflexión inconsciente- el origen de su flujo discontinuo ${ }^{22}$.

El aforismo espera ser contestado. No es solo discrepante respecto al lugar común sino que aguarda la reacción ajena por esa pulsión polemista y de litigio ya mencionada. Cuenta Geary una anécdota al respecto que resumo aquí. Un coleccionista se encuentra en una librería de segunda mano de San Francisco

17 Martínez, E., «Renuncia y proliferación: sobre los cuerpos inéditos de un libro de aforismos», en: Literatura y politica. Nuevas perspectivas teóricas, De Gruyter, Berlín 2019, pp. 154.

18 Citado por Helmich, o. c., p. 39.

19 Ibid., p. 39.

20 GEARY, J., El mundo en una frase. Una breve historia del aforismo, Ediciones Ceac, Barcelona 2007, p. 224.

21 Adorno, T. W., "L'aforisma come forma filosofica», Rigoni, M. A. (ed.), La brevità felice. Contributi alla teoria e alla storia dell'aforisma, Marsilio Editori, Venecia 2006, pp. 16.

22 Martínez, o. c., pp. 155 y 159. 
un volumen de aforismos de un tal Holbrook Jackson, cuyo ejemplar contenía una dedicatoria firmada a Chesterton. La peculiaridad es que los aforismos de Jackson habían sido replicados a lápiz verde por el propio Chesterton, uno a uno, en lo que constituye un auténtico combate entre aforismo y contraforismo. El aforismo, dice Geary, exige «o bien el reconocimiento de una percepción compartida (...) o bien un rechazo y una réplica» ${ }^{23}$.

Como viene reflexionando Juan Varo, puede considerarse un elemento central del aforismo su formulación de una verdad de la vida práctica. En el estudio de las particularidades del estatuto aleteico del aforismo, podría señalarse que ya los apotegmas tenían mucho de ello. Para Renzo Tosi, de las dos grandes tradiciones europeas del aforismo, la de la máxima francesa tendía a crear «preceptos de vida» ${ }^{24}$. Siguiendo lo ya planteado en su momento por Bacon, Cesare Viviani asegura que el aforismo adopta un tono axiomático pero surge de la incertidumbre; es un pensamiento asistemático y fragmentario. Mientras el pensamiento sistemático tiende a la abstracción, el aforismo se mantendría en contacto con la percepción que precede a su pensamiento y lo más próximo posible a la materia de lo que vive. Su especificidad tiene más que ver con la "materialidad de la experiencia que con la capacidad reflexiva» ${ }^{25}$. Para Adorno, el aforismo es una burla con la que la vida protesta ante la infertilidad de los sistemas religiosos y científicos, es un filosofar que nace de la discrepancia entre el ser y el pensamiento, que no pueden coincidir plenamente ${ }^{26}$. Partiendo de Laddove Krüger, Adorno desarrolla la idea del aforismo como una respuesta de la vida a la sistematización.

No es extraño por ello, según Salvatore Veca, que Hipócrates sintetizara normas concernientes a la vida práctica y que Schopenhauer llamara aforismos sobre la sabiduría de la vida a las máximas sobre «la infelicidad de la vida humana» que contienen sus Parerga y Paralipomena ${ }^{27}$. Para Viviani el aforismo también se aproxima lo máximo posible «a la materia viviente, al cuerpo» ${ }^{28}$. Reunidas a posteriori, las grandes reflexiones y las pequeñas notas de vida ordinaria quedan equiparadas sin jerarquía. En este sentido, quizás un libro de aforismos tenga, como diría Rancière, algo de sumidero, algo de fosa de la $\operatorname{verdad}^{29}$.

23 Geary, o. c., pp. 17 y 19.

24 Tosi, o. c., p. 1.

25 Viviani, C., "L'aforisma, gli intellettuali e i poeti», en: Eco et al., Teoria e storia dell'aforisma, Mondadori, Milán 2004, pp. 149-151.

26 Ibid., p. 16.

27 VECA, O. C., p. 125.

28 Viviani, o. c. p. 150.

29 Rancière, J., Politica de la literatura, El Zorzal, Buenos Aires 2003, p. 33. 


\section{ENUNCIADOS DE FICCIÓN}

En sus diferentes variantes históricas, el aforismo es convencionalmente definido como prosa de no-ficción. Aunque pueden constatarse numerosos ejemplos híbridos de libros de aforismos en verso (o en prosa con estructuras métricas ocultas), nos ceñiremos en adelante a la controversia de su posible ficcionalidad. Antes de detenernos en consideraciones teóricas, dejamos aquí las tres acepciones del término que ofrece el DRAE: 1. Acción y efecto de fingir; 2. Invención, cosa fingida; 3. Clase de obras literarias o cinematográficas, generalmente narrativas, que tratan de sucesos y personajes imaginarios. Obra, libro de ficción. Como he señalado en otro lugar:

las dos primeras acepciones parecen directamente válidas para el aforismo, que es producto de la invención y del fingimiento como toda obra literaria (la literatura no es verdadera sino verosímil: en ella tiene lugar una alianza entre retórica y poética destinada a impactar en la realidad humana). La tercera acepción, sin embargo, resulta parcial al señalar que las obras de ficción son «generalmente narrativas». Lo cual quiere decir que las obras «que tratan de sucesos y personajes imaginarios» no son siempre narrativas. ¿Qué otras obras son entonces ficticias? ¿En qué medida? La ambigüedad de la definición del DRAE es una muestra más de la confusión que rodea al término ${ }^{30}$.

Apoyándose en Harald Fricke y defendiendo la inserción del aforismo dentro del hipergénero de la "prosa de reflexión», Werner Helmich da cuenta de una vieja definición suya que le atribuye ausencia de "ficción narrativa» ${ }^{31}$. A continuación, añade sin embargo que ni siquiera la carencia de narratividad parece un rasgo esencial de este género, que es capaz de recurrir a la anécdota o a la historia breve para ilustrar una idea (igual que los exempla, las fábulas o los ensayos), así como de usurpar y hasta parodiar las formas gramaticales de la narración. Todas las grandes formas literarias, dice Helmich, son impuras ${ }^{32}$. Y, en lo que podríamos denominar una retórica del «como si», escribe Gómez Dávila: «El talento del escritor no está en describir un personaje, un paisaje, una escena, sino en hacernos creer que lo hizo» ${ }^{33}$.

Narratividad al margen, la posibilidad de un aforismo ficcional ha sido contemplada por teóricas como Ulrique Schneider en su ensayo sobre el aforismo poético contemporáneo ${ }^{34}$. Descartada por Helmich como innecesaria, la ficcionalidad del aforismo podría resultar relevante para evaluar el estatuto de verdad de sus enunciados y su relación contemporánea con la lírica. Para Ferrater Mora cabría distinguir entre el aforismo "puramente literario» y el filosófico, que tiene pretensión de verdad. Pero, incluso en su relación con la filosofía, los

30 Martínez, E., «Ideas en desbandada. Notas sobre el aforismo contemporáneo», en: Ínsula. Revista de Letras y Ciencias Humanas, n. ${ }^{\circ}$ 801, 2013, p. 5.

31 Helmich, o. c., p. 31.

32 Ibíd., p. 38-39.

33 Ibid., p. 204.

34 Cfr. Helmich, o. c., pp. 27-28 y 45. 
aforismos construirían para Ferrater proposiciones «formalmente falsas», porque «nada es verdad por sí solo» ${ }^{35}$. Quizás cabría alegar que la proposición de un aforismo nunca es «sola» a pesar de su apariencia retórica: lejos de la impermeabilidad que se le atribuye, su palabra construye vínculos mediante recursos específicos que van de la elipsis o la sinécdoque a la epifanía. Los aforismos se nutren entre sí y también por simbiosis de lo ajeno, como setas unidas bajo tierra y conectadas a las raíces de los árboles en un permanente intercambio.

Por su parte, Juan Varo escribía en 2012 sobre la posibilidad de desarrollar una variante del aforismo basada en la polifonía, con entradas capaces de negarse y discutir, como si fueran producto de un autor dubitativo o escindido en diferentes personajes ${ }^{36}$. Para Demetrio Fernández Muñoz, «al igual que cualquier género literario, el aforismo es capaz de crear ficción», como también piensa Hiram Barrios ${ }^{37}$. José Ramón González recurre al término «pseudoficción» para referirse a «aquellos textos que, siendo propiamente ficticios, permiten que el lector adivine o intuya una dimensión factual y un referente real», de forma que el texto ficticio sería opaco respecto al referente, el texto factual, transparente y el pseudoficticio, translúcido ${ }^{38}$. Antes de la distinción de Genette entre relato ficcional y factual, resulta clarificadora la realizada por Marie Laure Ryan entre las expresiones factuales (que describen el mundo real desde dentro), no factuales (describen otro mundo proyectándose imaginariamente en él sin renunciar a la propia realidad) y ficcionales (que implican el fingimiento de pertenencia a ese otro mundo descrito desde su interior ${ }^{39}$. Dentro de las ficcionales, Ryan diferencia entre las ficciones personales e impersonales, distinción esta fundamental para entender la naturaleza del aforismo, incluso en los casos en que se detecta un grado cero de individuación ${ }^{40}$.

¿Es operativa o no la categoría de ficción en el análisis del aforismo contemporáneo? Para responder a esta pregunta y considerando su ingrediente lírico, parece útil atender a las teorías ficcionales del poema ${ }^{41}$. En adelante, repasaré

35 Ferrater Mora, J., Diccionario de filosofía, Ariel, Barcelona 2009, pp. 71-72. En su definición del género, Ferrater Mora se apoya en las apreciaciones realizadas por Julián Marías en: Miguel de Unamuno, Espasa Calpe, Madrid 1943, pp. 12-13.

36 Caramagna, F., «L'aforisma in Spagna, Juan Varo Zafra», en: Aforisticamente. Aforismi, frasi e scritture brevi del XXI secolo, blog, en línea (consultado el 28 de septiembre de 2019): https://aforisticamente.wordpress.com/2011/06/06/laforisma-in-spagna-juan-varo-zafra/

37 Fernández Muñoz, D., Claves de la aforística española. Concepción del género, tradición literaria y eclosión en la posmodernidad. Tesis doctoral, Universidad de Alicante, 2017, p. 203, nota 274. Barrios, Hiram (comp.), Lapidario. Antología del aforismo mexicano (1869-2014), Secretaría de Educación del Gobierno de México, 2014, p. 26.

${ }^{38}$ Ibíd., p. 46.

39 Ryan, M.-L., «Fiction, Non-Factuals, and the Principle of Minimal Departure», en: Poetics, vol. 9, n. ${ }^{\circ}$ 4, August 1980, pp. 403-422.

40 Ryan, M.-L., «The Pragmatics of Personal and Impersonal Fiction», en: Poetics, vol. 10, n. ${ }^{\circ}$ 6, December 1981, pp. 517-539.

41 Para la consideración de la poesía como discurso ficticio hay una larga tradición que, durante los años 90, fue profundamente analizada en España por Pozuelo Yvancos (1991), A. Pérez Bowie (1992), Arturo Casas (1994), Fernando Cabo (1998 y 1999) o Sultana Wahnón 
algunas de sus claves, distanciándome de aquellos planteamientos que consideran que tanto el aforismo como la poesía se nutren de una esencia biográfica que los determinaría más que a otros géneros literarios. No es la dosis de autenticidad del elemento vivencial lo que determina la especificidad de un género literario, sino la forma en que este elemento se enuncia ${ }^{42}$.

Para Käte Hamburger la ficcionalidad o no ficcionalidad de un género está condicionada no tanto por el objeto de enunciación, que puede ser un invento, como por el sujeto enunciativo, que en el caso de un poema se correspondería con un sujeto empírico real. Siguiendo esta lógica, ni el poema ni el aforismo producirían un yo ficticio y quien escribe presentaría su discurso como enunciado desde un sujeto concreto con una vivencia particular del mundo, algo que los diferenciaría del drama o la narrativa. Frente a la experiencia de lectura de una novela, señala Hamburger, la lectura de un poema sería una experiencia de realidad. Algo extensible, según la percepción generalizada, al género del aforismo.

Un aforismo, sin embargo, no parece enunciativamente equiparable a un tratado científico, aunque Hamburger conciba a ambos y al mismo nivel como enunciados de realidad. Al igual que un poema, un aforismo es capaz de narrar. Puede producir heterónimos, coros y otros yoes ficticios. Aspira con frecuencia a una retracción utópica de la subjetividad o a un desapego radical de la representación que dota a su lenguaje, en algunas de sus manifestaciones contemporáneas, de una radical intransitividad ${ }^{43}$. Y esto sin olvidar que todas estas variantes tendrían diferente prevalencia dependiendo del momento histórico, la tradición y la poética. Pese a su apariencia monolítica, la enunciación de un aforismo es siempre problemática en tanto dialógica y capaz internamente

(1998), entre otros muchos. También podría, por supuesto, realizarse una comparativa con otros géneros considerados tradicionalmente como no ficticios. En un estudio sobre Julio Llamazares, Silvia Cárcamo analiza por ejemplo el pensamiento aforístico en relación con la reflexión autobiográfica del narrador español para quien «la memoria es una forma de ficción» (cit. por Silvia CÁRCAMO, «Del aforismo a la ficción: la memoria en Julio Llamazares», en: Espéculo: Revista de Estudios Literarios, n. ${ }^{\circ}$ 33, 2006. Disponible en línea: http://www. ucm.es/info/especulo/numero33/afollama.html).

42 Asumida la ficcionalidad de la lírica y más allá de la pragmática, teóricas como Sultana Wahnón han apelado a la elocución y la semántica para esclarecer la especificidad del género («Ficción y dicción en el poema», en: Teoría del poema: la enunciación lírica, F. Cabo y G. Gullón (eds.), Ámsterdam/Atlanta, Rodopi, 1998, pp. 77-110). Para Fernando Cabo, sería la debilidad o ausencia de circunstancia del discurso y del sujeto enunciador lo que lo caracterizaría al poema lírico moderno. En su enunciación, «el lenguaje se vuelve un tercero, casi en un sentido bajtiniano, presto a ocupar el protagonismo de la conciencia poética (...) Es el enunciado, lo dicho en el poema, quien rige la enunciación y, en consecuencia, la problematiza e incluso, en algún caso, la anula. Sólo así la lírica se vuelve l'art consacré aux fictions de que hablaba Mallarmé» («Entre Narciso y Filomela. Enunciación y lenguaje poético», o. c., pp. 19 y 29).

43 Escribe Cabo: «Mediante un proceso de ascesis, la ficción se mantiene, pues, como concepto relevante, pero a costa de haberlo despojado de sus conexiones con la enunciación y con la representación» (Ibid., p. 23). 
de la escenificación. No puede olvidarse, además, que los aforismos de fórmula impersonal y los que recurren a la primera persona están interferidos por figuras operantes de la tradición, como la del parresiasta, el sabio loco o el misántropo lapidario. Escribe Gómez Dávila: «Lo que el escritor inventa primero es el personaje que escribirá sus obras» ${ }^{44}$.

Partiendo de estos planteamientos, no creo posible hablar de la existencia de una subjetividad real, que en el caso de la poesía "confesaría sus emociones» y en el caso del aforismo «expresaría sus verdades». Ambos discursos son, como diría Pérez Bowie, «ficcionalizaciones del yo real» ${ }^{45}$. Y no lo son por su relación con el referente ni porque produzcan mundos posibles, imaginados o irreales, sino:

1. Por la imposibilidad de identificarla con un sujeto monológico, real y concreto.

2. Por la red complejísima de discursos propios y ajenos, memorias personales y colectivas, tradiciones literarias, culturales y míticas que se cruzan en ella.

3.Y porque, incluso cuando el sujeto enunciativo se propone como real, como centro del discurso y recurre a la primera persona, un aforismo no deja por ello de ser un acto verbal representado, enunciado por un hablante ficticio.

Nada de esto convierte en falso lo que dice un aforismo: ni el lenguaje ni la ficción son estorbos en el trato con la verdad. Pero hace mucho que la subjetividad que poesía y aforismo producen no puede ser otra cosa que dialógica, precaria o reticente, siendo a su vez el sujeto que la enuncia producto de la figuración, de la representación o imaginario ${ }^{46}$. En un aforismo no es posible separar la experiencia de verdad y la enunciación de esa experiencia: su conocimiento está, como diría Valente, «haciéndose» ${ }^{47}$.

44 Gómez Dávila, N. Escolios a un texto implícito, Atalanta, Gerona 2009, p. 123.

45 Pérez Bowie, J. A., «Para una tipología de los procedimientos metaficcionales en la lírica contemporánea», en: Tropelías, n. ${ }^{\circ}$ 3, 1992, p. 95.

46 Sobre la consideración de la enunciación del poema como un «soliloquio imaginario» y el sujeto poético como figuración o representación puede consultarse a Carlos Bousoño (1952), Martínez Bonati (1960) o Barbara H. Smith (1971). Desde los años 90, desde la Universidad Nacional de Mar del Plata, Laura Scarano, Marcela Romano y Marta Ferrari vienen desarrollando una teoría del "correlato autoral» y el sujeto en la poesía española (1994, 1996, 2000 y 2007). Ya en 2011, Scarano ha trabajado con el concepto de «metapoeta» entendido como "autor que escribe al autor que escribe» («Metapoeta: el autor en el poema», en: Boletín Hispánico Helvético. Historia, teoría(s), prácticas culturales. Sociedad Suiza de Estudios Hispánicos, n. ${ }^{\circ} 17-18,2001$, pp. 323-324). En sus aportaciones a los seminarios internacionales sobre semiótica editados por José Romera Castillo y Francisco Gutiérrez Carbajo en 1993 y 2000, el propio Romera Castillo, Darío Villanueva, Túa Blesa, Antonia Cabanilles, Genara Pulido, Alicia Molero o Antonio Gil entienden el «poema autobiográfico» como una subcategoría dentro de las «escrituras del yo» (cfr. Scarano, o. c., p. 328).

47 Valente, J. A., "Conocimiento y comunicación», en: Las palabras de la tribu, Siglo Veintiuno, Madrid 1971, p. 7. 
La definición del aforismo como «expresión monadológica» — siguiendo la terminología leibziniana- forma parte de la definición del género que hace el Diccionario de Filosofía de Gabriel Ferrater y ha sido defendida, entre otros, por Ana Bungaard. De ser aplicable, creo que el monologismo del género es más propio de las máximas (totalizadoras y cerradas en sus proposiciones) que del aforismo contemporáneo, y resulta tan discutible, en todo caso, como la categorización de la poesía que hizo Mijaíl Bajtín ${ }^{48}$. Desde el planteamiento que vengo desarrollando, la ficcionalidad no depende finalmente de la posible asunción de un personaje, máscara, heterónimo. Ni tampoco de la aceptación del monólogo dramático, ese lugar común de la teoría poética contemporánea planteado por la crítica anglosajona y ampliamente trabajado en España mediante una revisión histórica que va de las cantigas de amigo, Ibn Ezra o las tablas de Cascales a los apócrifos de Machado o la poesía de la experiencia. La ficcionalidad depende, como se ha dicho con anterioridad, de los modos de enunciación del discurso literario ${ }^{49}$.

Obviando la ingenua identificación del sujeto enunciador con el autor empírico, la del destinatario del texto con el lector real o la posible inventiva de la idea formulada, el acto verbal de un aforismo es tan ficticio como el de un poema. Lo cual no quita, por supuesto, que ambos se diferencien de la narrativa o el teatro, y también entre sí por múltiples razones. El lector de un libro de aforismos no reproduce el pensamiento de su autor, sino que actualiza la búsqueda figurada de la verdad mediante una revelación epifánica del sentido. ¿Y por qué se mantiene, entonces, la ilusión de verdad individual? Al respecto, he señalado en otro sitio que «quizás, igual que un poema, un aforismo sea una ficción de no-ficción (...). Un aforismo o un poema no son más autobiográficos ni más honestos que una novela, pero fingen serlo. Y es en ese fingimiento, en esa ficción autobiográfica donde descansa su pacto específico con el lector» ${ }^{50}$. Al menos desde el Romanticismo. Para Carlos Marzal, la fuerza y justeza de un aforismo «dependen en buena medida de una momentánea ficción: el hecho de que sintamos como único el aforismo, la formulación de una exactitud inesperada, y como único también el núcleo sobre el que se medita (...). Algo que sabemos completamente falso, pero que sentimos como verdadero por completo ${ }^{51}$.

48 Una discusión sobre el tema puede encontrarse en: MARTínez, E., «Políticas estéticas del pensamiento bajtiniano: hacia una dialogía poética», en: Badebec. Revista del Centro de Teoría y Crítica Literaria, vol. 7, n. ${ }^{\circ}$ 13, septiembre de 2017, pp. 240-259.

${ }_{49}$ En este punto es interesante subrayar, con S. Wahnón, que la cuestión enunciativa es necesaria para esclarecer el carácter de ficción del poema lírico (o del aforismo, podríamos añadir), pero no basta para analizar en qué se distingue dicho género de otras ficciones como la del teatro o la novela (Ibíd., p. 106).

50 Martínez, E., "Ideas en desbandada. Notas sobre el aforismo contemporáneo», en: Ínsula. Revista de Letras y Ciencias Humanas, nº 801, 2013, p. 4.

51 Marzal, C., «Lo breve interminable (el aforismo y la escritura poética)», en: M. A. Naval (ed.), Poesía española posmoderna, Visor, Madrid 2010, pp. 154-155. 
La exigencia implícita de «autenticidad» que lleva al aforismo y al poema a constituirse como ficciones de no-ficción supone ya una diferencia con otros géneros como la novela o el teatro. En la voluntad de acotar esa especificidad, podríamos sucumbir a dos tentaciones:

1. Establecer una diferencia entre aforismos de ficción y no ficción, atendiendo, por ejemplo, a su narratividad o a la asunción explícita de una máscara o personaje.

2. Establecer una gradación ficcional, según la cual el elemento ficticio de un aforismo sería poco relevante (o ausente) y el de una novela, definitorio.

Ninguna de las dos opciones resulta del todo satisfactoria porque la ficcionalidad de un discurso depende de la propia enunciación, como se dijo antes: es o no es, de forma categórica y no progresiva. En los aforismos formulados en primera persona, el sujeto enunciativo puede ser entendido como una función del texto. En los aforismos de narración o máscara, quien escribe hace mucho más que impostar y referir. Y en los aforismos que esconden al sujeto enunciativo, asistiríamos - como en algunos poemas y narraciones-a una ficción impersonal.

A quienes detectan la posible identificación entre las ideas contenidas en un libro de aforismos y las de su autor, podría responderse que dicha similitud es imposible de verificar, que los libros de aforismos contienen ideas que a menudo se contradicen entre sí y que es perfectamente viable defender en un aforismo una idea con la que no se está de acuerdo: porque la intuición literaria te lleva a sospechar de tus propios fundamentos; porque la coherencia de tu personaje lo requiere; porque la contraposición paradójica entre dos aforismos puede producir verdad, etc. Apunta Gómez Dávila: «Es difícil hacerle entender al tonto que la filosofía, precisamente, es el arte de contradecirse mutuamente sin anularse ${ }^{52}$.

Desde una órbita más semántica que pragmática, la ficción ha sido conceptualizada también en su vínculo con la creación de mundos imaginados. El límite en este punto es la identificación restrictiva de «mundo imaginado» con «personajes», «acciones» o incluso «objetos» imaginados, quedando fuera habitualmente los universos de pensamiento y metafóricos. Incluyendo a estos últimos, podríamos afirmar que el mundo imaginado por un libro de aforismos es, por lo general, una ficción de pensamiento verosímil, aunque las variantes del aforismo lírico han traído también al género la posibilidad fantástica y metafórica de la ficción inverosímil. Esto permite no contraponer, por ejemplo, las teorías de Doležel a la propuesta del aforismo como género de ficción, algo que ya ha señalado Pozuelo Yvancos para la poesía ${ }^{53}$. Y ello aunque el mundo ficticio de un libro esté, como señala Arturo Casas,

\footnotetext{
52 Ibid., p. 110.
}

53 De sus numerosos trabajos sobre teoría del poema se puede ver, por ejemplo, Pozuelo Yvancos, J. M., “¿Enunciación lírica?», en: Diálogos Hispánicos, n. ${ }^{\circ} 21,1998$, pp. 41-76. Sobre la pertinencia de los mundos imaginados para la consideración de la ficción de la poesía, ver: CASAS, A., "Pragmática y poesía», en: Darío Villanueva (comp.), Avances en Teoría de la Literatura, Universidad de Santiago de Compostela, 1994, pp. 229-308. 
perfilado apenas con los trazos de la simple connotación y sin aspiraciones de cerrar —o de invitar a cerrar a través del proceso de lectura- en cuanto constructo aquel marco. Como ha señalado Lubomír Doležel, y a ello apunta también la ontología literaria ingardeana, todo mundo ficcional se constituye de modo esquemático e incompleto, de modo que podría hablarse de una deficiencia lógica en su constitución que es a la vez un elemento importante de la propia eficiencia textual ${ }^{54}$.

\section{De la Parresía a los hypomnemata: lecturas de Foucault}

Con diferentes formulaciones a lo largo de su historia, el aforismo ha venido desarrollando por una vía gnómica y metafórica una relación cruda con la franqueza. Esta peculiaridad puede vincularse con el «decir verdad»sobre el que Foucault escribiera en sus dos últimos seminarios. Desde una doble naturaleza filosófico-poética, el aforismo contemporáneo pone en juego unos procesos específicos de subjetivación que constituyen una ontología política, siendo su tendencia a la paradoja — como ha señalado Azucena González Blanco— un ejemplo paradigmático de la conexión establecida por el último Foucault entre los modos discursivos y los discursos de la sinrazón ${ }^{55}$. El desacuerdo es, en su caso, un ejercicio radical de la verdad, una forma de la parresía que:

conlleva un "estar en peligro»" por lo que se dice. Los términos en que Foucault describe esta habla peligrosa coinciden con la definición de paradoja como «contraria a la opinión». El hecho de que un hablante dijera algo peligroso, es decir, «diferente de lo que cree la mayoría», era una fuerte indicación de que el que hablaba era un parresiastés. Si en un debate político, un orador se arriesgaba a perder su popularidad «porque sus opiniones eran contrarias a la opinión de la mayoría» o podían desembocar en un «escándalo» político, utilizaba la parresía ${ }^{56}$.

En segundo lugar, hay que señalar que el aforismo pone en práctica determinados «juegos de verdad» o «discursos de veridicción» capaces de constituir históricamente al ser como experiencia. El aforismo genera planos múltiples con innumerables posibilidades de combinación que mantienen en un estado inconcluso su libro venidero. Su dispersión y diversidad garantizan la pervivencia del acontecimiento en su singularidad, tal como la concibió Foucault en su análisis de los fragmentos nietzscheanos ${ }^{57}$.

\footnotetext{
54 Ibid., p. 288.

55 González Blanco, A., "Aforismo y paradoja. El caso de Carlos Pujol», en: Ínsula. Revista de Letras y Ciencias Humanas, n. ${ }^{\circ} 801$, p. 25-26.

56 Ibid., p. 26.

57 Foucault, M., Dits et écrits, tomo 1 (1954-1988), texto n. ${ }^{\circ}$ 45, Gallimard, París 1994 , pp. 561-564.
} 
Recurriendo al concepto de «inequivalencia», utilizado por Jean-Luc Nancy para pensar el paradigma democrático ${ }^{58}$, puede decirse que cada aforismo posee - dentro del libro que integra - un valor propio que construye su verdad pero cuya verdad remite al resto; materializa la apertura del sentido singular de cada uno y de cada relación. El aforismo podría ser conceptualizado, en este sentido, como una herramienta contra el nihilismo: igual que todo sujeto, un aforismo posee en sí mismo un valor ilimitado. Su naturaleza, incompleta por definición, es un laboratorio idóneo, por ello, para la articulación de lo que Nancy ha llamado una "pluralidad de singulares", donde los aforismos no serían partes de un todo primigenio, sino que constituirían desde su origen una multitud de singularidades absolutas ${ }^{59}$.

Regresando al concepto de verdad desarrollado en «La escritura de sí», podría atenderse a las convergencias del aforismo con los hypomnemata de la Antigua Grecia, que Foucault juzga eslabones importantes en la subjetivación del discurso ${ }^{60}$. De este antepasado pervive en el aforismo su carácter de «verdad inconexa», entendida como una manera de combinar la autoridad tradicional de lo dicho con la particularidad de la verdad que en ella se afirma. Igual que los hypomnemata, el ejercicio de lectura, relectura y meditación de un aforismo ofrece la posibilidad de conversar consigo mismo y con otros, constituyendo un «logos bioético», un bagaje de discursos disponibles, capaz de socorrer ${ }^{61}$. Partiendo de aquí, podría entenderse al aforismo contemporáneo como una práctica regulada y voluntaria de la disparidad que, mediante una elección de elementos heterogéneos, se opone a la unidad doctrinal y a toda forma tradicional de sistematización del pensamiento. Como dice Foucault:

Lo esencial es que se pueda considerar la frase retenida como una sentencia verdadera en lo que afirma, conveniente en lo que se prescribe, útil según las circunstancias en que se encuentre. La escritura como ejercicio personal hecho por sí y para sí es un arte de la verdad inconexa o, más precisamente, una manera reflexiva de combinar la autoridad tradicional de la cosa ya dicha con la singularidad de la verdad que en ella se afirma y la particularidad de las circunstancias que al respecto determinan su uso ${ }^{62}$.

Atendiendo a su función en nuestros días, resulta tentador considerar al aforismo como un reducto de la palabra desde el que discutir el cinismo relativista posmoderno y el reinado de la posverdad. En su pragmática de la comunicación

58 En La verdad de la democracia, escribe Nancy que el futuro de la democracia dependerá de la transformación del paradigma de la equivalencia, o sea, de la creación de una nueva inequivalencia que se diferencie de la dominación económica, el feudalismo, los regímenes de elección divina y los esteticismos (ver: La vérité de la démocratie, Galilée, París 2008, pp. 45-46).

59 Nancy, J.-L., Ser singular plural, Arena, Madrid 2006, p. 55.

60 Sobre el tema puede verse: Foucault, M., Estética, ética y hermenéutica. Obras esenciales. Vol. III, Paidós, Barcelona 1999, pp. 292-297.

61 Ibid., 293.

62 Ibid., 295. 
literaria, Van Dijk introdujo el concepto de «acto de habla ritual» para nombrar «un tipo de acto ilocutivo que implica la intención de cambiar la actitud del oyente con respecto al contexto (texto, hablante, etc.), especialmente las actitudes valorativas del oyente» ${ }^{63}$. La literatura sería así un acto de habla ritual institucionalizado y puede que, dentro de ella, el aforismo constituya un ritual de la verdad.

Universidad de Granada

ERIKA MaRTíneZ

erikamc@ugr.es

[Artículo aprobado para publicación en febrero de 2020]

63 Dijk, Teun A. van, «La pragmática de la comunicación literaria», en: José Antonio Mayoral (comp.), Pragmática de la comunicación literaria, Arco Libros, Madrid 1987, p. 183. El subrayado es mío. 